medRxiv preprint doi: https://doi.org/10.1101/2021.07.10.21260297; this version posted July 14,2021 . The copyright holder for this preprint (which was not certified by peer review) is the author/funder, who has granted medRxiv a license to display the preprint in perpetuity. It is made available under a CC-BY-NC-ND 4.0 International license.

\title{
Does trust in government improve Covid-19's crisis management?
}

\author{
Ablam Estel Apeti*,1 \\ ${ }^{1}$ Université Clermont Auvergne, CNRS, IRD, CERDI, F-63000 Clermont-Ferrand, France
}

\begin{abstract}
Countries have adopted several measures to control the spread of Covid-19. However, substantial differences remain in terms of performance in controlling the virus, potentially due to heterogeneity in citizen engagement with government measures. Drawing on this observation, this paper seeks to analyze the effect of pre-crisis ties, particularly trust in government, on crisis management, proxied by the number of Covid-19 cases and deaths per million population. We examine this question based on a sample of 41 countries for which data are available. Results reveal that a high level of trust in government predicts better crisis management in terms of relatively low levels of cases and deaths. These results, which successfully pass a series of robustness tests, may vary according to level of contamination and increase with time.
\end{abstract}

JEL Classification: E71, H12, I12, I18, I38, Z18

Keywords: Covid-19, containment measures, trust in government, recovery plans

\section{Introduction}

In response to Covid-19, most countries have implemented non-pharmaceutical interventions ranging from physical distancing to non-essential (internal) movement restrictions, i.e., lockdown, ${ }^{1}$ and more recently, vaccination campaigns, to control the virus and save lives. Although the effect of these policies remains relatively positive on pandemic management (Acemoglu et al., 2020; Caselli et al., 2020; Cowling et al., 2020; DemirgucKunt et al., 2020), the levels of cases and deaths - proxy of crisis management — due to Covid-19 vary across countries or regions. ${ }^{2}$ This heterogeneity in the crisis management

*ablam_estel.apeti@uca.fr

1. See https://www.bbc.com/news/world-52103747 for various albeit similar policies implemented by countries.

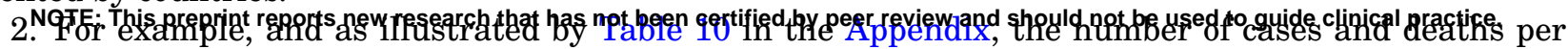
million population varies widely, with differences between the maximum and minimum of 47496.53 and 1206.92 respectively. 
medRxiv preprint doi: https://doi.org/10.1101/2021.07.10.21260297; this version posted July 14, 2021. The copyright holder for this preprint (which was not certified by peer review) is the author/funder, who has granted medRxiv a license to display the preprint in perpetuity.

It is made available under a CC-BY-NC-ND 4.0 International license.

indicates that compliance to policies put in place by governments may depend on some countries' characteristics, especially citizens' commitment. In particular, the ability of people to comply with government policies, and consequently the government's ability to control the pandemic, may depend, like any other public policy response, on citizens' trust in their government. ${ }^{3}$

Although the literature on the Covid-19 pandemic remains sizeable, little is said about the role of trust in government ${ }^{4}$ on the management of the crisis in terms of the number of cases and deaths. It is important to note that one paper that addresses a similar question is Gelfand et al. (2021). However, a major difference exists. Indeed, these authors analyze the effect of cultural tightness-looseness on the number of cases and deaths, while our goal is to focus on citizens' trust in their government. ${ }^{5}$ In most existing papers, trust is presented as a determinant of compliance to government health policies and hardly as a determinant of mortality, or more importantly, of the virus' spread, i.e., contaminations or number of cases. This paper will fill this gap by analyzing the effect of pre-Covid trust in government on crisis management based on the number of cases and deaths per million population. Our results based on Ordinary Least Squares (OLS) on 41 countries show that high pre-crisis trust predicts better crisis management through lower numbers of cases and deaths per million population. This finding remains robust to alternative crisis management measures such as numbers of new cases and deaths per million population, number of hospitalized patients per million population, number of Intensive Care Unit (ICU) patients per million population, excess mortality during the pandemic, and Covid Performance Index. In addition, robustness tests performed by altering the sample, using alternative definitions of trust, and adding additional controls failed to alter our conclusions. The heterogeneity tests conducted later reveal that the trust effect may depend on the level of contamination, with a larger magnitude above 100 cases per million population, and increases over time i.e., between the first (2020)

3. Indeed, trust is identified in the literature as an essential precondition for successful regulation and people's ability to comply with the rule of law (see for instance https://www.oecd.org/gov/ trust-in-government. htm. In current times where regulation of the economy and compliance to government guidelines appears necessary, trust appears to be very important

4. In this paper, trust in government and trust are used interchangeably.

5. While it is reasonable to think that cultural tightness-looseness and trust in government may be "strongly" related (see for instance Aktas et al., 2016; Su et al., 2016 or https: / / harvardpolitics . com/culture-response-covid-19/), statistical tests seem to tell a fairly opposite story with a nonsignificant correlation coefficient of 0.20 for countries in our sample. Later in the paper, we control for cultural tightness-looseness to better isolate the effect of trust in government on the pandemic management. 
medRxiv preprint doi: https://doi.org/10.1101/2021.07.10.21260297; this version posted July 14, 2021. The copyright holder for this preprint (which was not certified by peer review) is the author/funder, who has granted medRxiv a license to display the preprint in perpetuity.

and second (2021) years of the pandemic.

The rest of the paper is organized as follows. Section 2 presents the arguments linking trust and Covid-19 management. Section 3 discusses the data and some descriptive statistics. Section 4 presents the methodology. Sections 5 and 6 discuss the results and robustness tests respectively. Section 7 highlights some conditions under which our baseline findings may vary, and Section 8 concludes.

\section{The argument}

Three main arguments support the idea that the pre-Covid trust can influence pandemic management.

First, trust can support the creation of broad (pre-crisis) policy space for government intervention related to Covid-19. ${ }^{6}$ Various studies, including Schaltegger and Torgler (2005) and OECD (2013) show a positive association between trust and fiscal discipline in terms of lower public debt accumulation. Illustrative examples are the Nordic countries, in particular Denmark and Sweden, which exhibit high levels of trust and fiscal discipline (low debt) compared to most developed countries. ${ }^{7}$ This pre-pandemic fiscal discipline may ease the creation of significant fiscal space for stimulating the economy, providing transfers and social assistance in order to mitigate crisis collateral damage ${ }^{8}$ and amplifying factors such as unemployment, mental health problems, suicides and many others (Chiappini et al., 2020; Holman et al., 2020; Kola, 2020; Panchal et al., 2020; Silverio-Murillo et al., 2021). ${ }^{9}$

Second, trust can help manage the pandemic by ensuring public compliance with government-announced health policies. As previously reported, in response to the rapid

6. Furthermore, corruption, i.e., poor institutional quality, is another serious source of distrust between governments and the governed. Thus, higher trust between governments and citizens can arise from the better institutional quality, particularly through better corruption levels, paving the way for a prepandemic institutional situation suitable for transparent and efficient pandemic management.

7. https://knowablemagazine.org/article/society/2021/ danger-high-public-debt-is-not-what-you-think

8. For example, in France, in order to limit these damages, some devices such as specialists' consultation like psychologists were put in place.

9. See https://wellbeingtrust.org/areas-of-focus/policy-and-advocacy/reports/ projected-deaths-of-despair-during-covid-19/ which also exposes collateral damage and amplifying factors of the crisis, in particular the "deaths of despair" tragedy caused by the implementation of various containment policies. Note that three factors, already at work, are exacerbating "deaths of despair": unprecedented economic failure paired with massive unemployment mandated social isolation for months and possible residual isolation for years, and uncertainty caused by the sudden emergence of a novel, previously unknown microbe. 
medRxiv preprint doi: https://doi.org/10.1101/2021.07.10.21260297; this version posted July 14, 2021. The copyright holder for this preprint (which was not certified by peer review) is the author/funder, who has granted medRxiv a license to display the preprint in perpetuity.

spread and growing death toll, and due to limited available and/or "widely" approved therapies, most governments have implemented non-pharmaceutical measures such as physical distancing, travel restrictions/bans, masks, stay-at-home orders, or regular hand washing. However, compliance with these strict measures that change the way millions of people live is not always deliberate. For example, in some parts of the world, these measures are perceived as a clear desire of (national) governments to control and restrict individual liberties, leading to protests, boycotts, and, to some extent, civil unrest. Existing studies show that compliance to these measures depends on people' trust in their government (Yaqub et al., 2014; Blair et al., 2017; Bargain and Aminjonov, 2020). Thus, trust appears to play a key role in successful containment programs and potentially in the willingness of individuals to believe in science and adhere to new measures, mainly pharmaceutical such as vaccination, to tackle the virus, as documented in several studies (Woskie and Fallah, 2019; Deb et al., 2020; Hosny, 2021; Pagliaro et al., 2021).

Finally, trust can undermine sound management of the pandemic, by, for example, promoting less skilled governments. Indeed, excessive trust can lead citizens to naively believe that government is effectively managing the pandemic when it is not (Devine et al., 2020), possibly creating excessive levels of infections and deaths. On the other hand, low trust of citizens in politicians may favor populist parties (Keefer et al., 2021), which to date has shown less efficiency in managing the pandemic (example of Brazil).

In summary, putting these three arguments together, we can assume that the effect of trust on crisis management can be transmitted through three channels, namely the creation of relevant pre-Covid economic policy space for quick reaction in response to the crisis, the commitment of citizens to comply with government health policies or virus control measures, and the cover-up of government's real capacity to effectively manage the health crisis and/or the implications of populist parties' expansion. The contradiction revealed by these three channels shows that the effect of trust on the pandemic's management is ambiguous, making the question more empirical than theoretical.

\section{Data and first impressions}

In this section, we describe the key variables in our paper and underscore some statistical evidence that characterizes the relationship between trust and Covid-19 crisis 
medRxiv preprint doi: https://doi.org/10.1101/2021.07.10.21260297; this version posted July 14, 2021. The copyright holder for this preprint (which was not certified by peer review) is the author/funder, who has granted medRxiv a license to display the preprint in perpetuity. It is made available under a CC-BY-NC-ND 4.0 International license .

management.

\subsection{Data}

Our analysis is based on cross-sectional data of 41 countries with a geographical scope covering the five continents and including the following variables:

Trust in government. Trust in government refers to the share of people who report having confidence in the national government. The data shown reflect the share of respondents answering "yes" (the other response categories being "no", and "don't know") to the survey question: "In this country, do you have confidence in ... national government?". The sample is ex-ante designed to be nationally representative of the population aged 15 and over. This indicator is measured as a percentage of all survey respondents. For our analysis, we use pre-Covid trust chiefly to remove any potential effects of the crisis management and thus assess the role of differences in structural characteristics such as norms, values, and especially trust on the pandemic management pathway. ${ }^{10}$ For our primary measure, we consider average trust over 2018-2019. To test the robustness of our results, we used alternative trust measures by taking an average over the period 2006-2019, 2006-2019 without the Global Financial Crisis (GFC) period, using only 2019 observations. The data are from OECD (2021). In addition, we used the European Social Survey (ESS) database, which allows us to define three alternative trust measures: trust in politicians, citizens' satisfaction with the work of the national government, and citizens' satisfaction with the way democracy works in their country.

Covid-19 crisis management. We use two main measures for crisis management, namely the (total) number of cases and deaths per million population (virus prevalence). For robustness concerns, we use alternative measures of crisis management. First, we use pandemic incidence instead of prevalence captured by the number of new cases and deaths per million population. Second, we use the number of hospitalizations and Intensive Care Unit (ICU) patients admissions due to Covid-19. Third, we select excess mortality during the Covid-19 crisis, in particular P-score, which captures how the number of weekly or monthly deaths in 2020-2021 differs as a percentage from the average number of deaths during the same period over the years 2015-2019. Put another way,

10. In other words, we use a pre-crisis measure of trust that remains completely unaffected by Covid-19 crisis management. This choice allows us to capture the role of differences in civic norms and trust in the political system that existed in the countries in our sample. 
medRxiv preprint doi: https://doi.org/10.1101/2021.07.10.21260297; this version posted July 14,2021 . The copyright holder for this preprint (which was not certified by peer review) is the author/funder, who has granted medRxiv a license to display the preprint in perpetuity.

It is made available under a CC-BY-NC-ND 4.0 International license.

excess mortality is an epidemiology and public health term that refers to the number of deaths from all causes occurring during a crisis that exceed what would have been expected under "normal" conditions. In this case, we are interested in comparing the number of deaths that occurred during the Covid-19 pandemic to the number of deaths we would have expected had the pandemic not occurred - a crucial quantity that cannot be known but can be estimated in several ways. Excess mortality mitigates the number of deaths restriction by taking into account the total impact of the pandemic on deaths instead of solely Covid-19 confirmed deaths. Specifically, this variable takes into account not only confirmed deaths, but also Covid-19 deaths that were not properly diagnosed and reported, as well as deaths due to other causes that are attributable to the general conditions of the crisis. ${ }^{11}$ The data come from Hannah Ritchie and Roser (2020). Finally, we pick Lowy Institute's Covid Performance Index (CPI) as an alternative proxy of crisis management. This measure provides a ranked comparison of the performance of countries in managing the Covid-19 pandemic in the 43 weeks following their hundredth confirmed case of the virus, using data available to March 13, 2021 and is computed based on the following variables: confirmed cases, confirmed deaths, confirmed cases per million people, confirmed deaths per million people, confirmed cases as a proportion of tests, and tests per thousand people.

Macroeconomic variables. Macroeconomic variables from World Development Indicators (WDI) include data on real GDP per capita growth and trade openness.

Demographic and fiscal variables. Data from the WDI and the IMF's World Economic Outlook (WEO) databases include population density and public expenditure over GDP.

Health preparedness. Data on hospital beds per thousand inhabitants are obtained from Hannah Ritchie and Roser (2020). Descriptions and sources for every variable used in this paper, as well as the sample composition, are provided in the Appendix.

\subsection{First impressions}

To get an idea on the relationship between trust ${ }^{12}$ and Covid-19 crisis management, we start with some statistical regularity. Figure 1 shows a correlation between trust and

11. See also https://ourworldindata.org/covid-excess-mortality and https://www. who. int/data/stories/the-true-death-toll-of-covid-19-estimating-global-excess-mortality

12. Note that trust and level of development are strongly related. To take this into account and produce more informative statistics, we use a residual approach by adjusting trust to the level of development. 
medRxiv preprint doi: https://doi.org/10.1101/2021.07.10.21260297; this version posted July 14, 2021. The copyright holder for this preprint (which was not certified by peer review) is the author/funder, who has granted medRxiv a license to display the preprint in perpetuity. It is made available under a CC-BY-NC-ND 4.0 International license.

the number of Covid-19 cases on the one hand, and between trust and number of deaths on the other hand. Irrespective of the measure of crisis management used, a negative association with trust is observed. In other words, a high pre-crisis level of trust in government is associated with better management of the Covid-19 crisis materialized by a relatively low number of cases and deaths. Table 1 extends this observation by computing the number of cases and deaths according to the level of trust. ${ }^{13}$ The results reveal that countries in which citizens have high trust in government are dealing well with the crisis. Specifically, high trust countries exhibit contaminations (deaths) per million population of 18211.73 (333.90) versus 22764.65 (609.55) for low trust countries. Compared to low trust countries, these results indicate that high trust countries experience $20 \%$ and $45.22 \%$ reduction in contaminations and deaths over January 1, 2020 to May 26, 2021.

Keeping these descriptive relationships in mind, we develop a more formal analysis in the following section to capture the causal effect of trust, i.e., the impact on the Covid-19 crisis management signaled by the number of cases and deaths per million population.
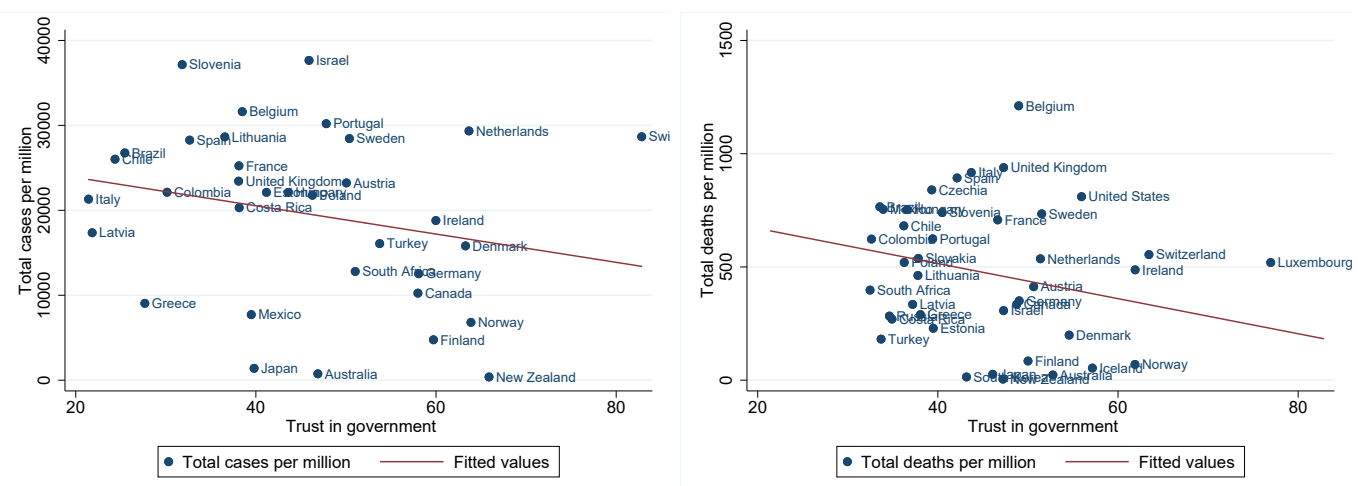

Figure 1 - Corelation between trust and Covid-19 crisis management Source: Authors' calculations

13. The classification of countries is based on the position in relation to the sample median. Thus, countries with a higher trust level are those above the sample median, and those below the median are classified as having a lower trust level. 
medRxiv preprint doi: https://doi.org/10.1101/2021.07.10.21260297; this version posted July 14, 2021. The copyright holder for this preprint (which was not certified by peer review) is the author/funder, who has granted medRxiv a license to display the preprint in perpetuity. It is made available under a CC-BY-NC-ND 4.0 International license .

Table 1 - Covid-19 crisis management by trust level

\begin{tabular}{lccc}
\hline & High trust & Low trust & Diff \\
\hline & & & \\
Total cases per million & 18211.73 & 22764.65 & 4552.922 \\
Total deaths per million & 333.8951 & 609.5477 & 275.6526 \\
Obs & 20 & 21 & \\
\hline
\end{tabular}

\section{Methodology}

In this section, we first present the model used to test our question and then we develop our identification strategy.

\subsection{Model}

We estimate the effect of trust on the Covid-19 crisis management using a crosssection model :

$$
\text { Crisis_management }{ }_{i}=\beta_{0}+\beta_{1} \text { trust }_{i}+\beta_{2 j} X_{i}^{j}+\varepsilon_{i},
$$

with Crisis_management ${ }_{i}$ the Covid-19 crisis management of country $i$, $_{\text {trust }}$ the (preCovid) trust in government of country $i, X_{i}^{j}$ the vector of $j$ control variables, and $\varepsilon_{i}$ the error term.

The choice of control variables, including population density, public expenditure, hospital beds per thousand, trade openness, and real GDP per capita growth, is based on their potential effect on trust but also on the pandemic management. For example, high population density may lead to rapid circulation of the virus due to strong social or physical interaction, making crisis management more difficult. This is the typical case of large cities which generally exhibit large size of the crisis. On the other hand, good pre-crisis public expenditure and hospital bed availability can improve countries' preparedness to manage the crisis. Meanwhile, good pre-pandemic economic conditions as tracked by real GDP per capita growth can shape pre-existing trust between politicians or policymakers and citizens. The effect of trade openness may seem ambiguous. Indeed, trade openness can improve countries' economic situation and thus create a strong trust relationship. On the other hand, high openness can result in strong dependence on foreign countries for some essential goods needed for managing the pandemic, such as masks, hydroalcoholic gels, or drugs (Barlow et al., 2021). This is the case of some countries that suffered, especially at the beginning of the pandemic, to have the necessary tools for the 
medRxiv preprint doi: https://doi.org/10.1101/2021.07.10.21260297; this version posted July 14, 2021. The copyright holder for this preprint (which was not certified by peer review) is the author/funder, who has granted medRxiv a license to display the preprint in perpetuity. It is made available under a CC-BY-NC-ND 4.0 International license .

protection of their population and the limitation of the spread of the virus. The parameter of interest is $\beta_{1}$ : to confirm our hypothesis, $\beta_{1}$ should be statistically significant and indicate a favorable effect of higher pre-Covid trust on the pandemic management. In other words, we expect a negative and statistically significant sign for our parameter of interest.

\subsection{Identification strategy}

One analysis that explores the effect of trust on the Covid-19 crisis may suffer from an endogeneity problem, namely, reverse causality. Indeed, the quality of crisis management can affect citizens' trust in their government. One example is France, where statistics show substantial variations in citizens' trust in their government since the start of the crisis due to health policies implemented. ${ }^{14}$ More formal studies, such as Jennings (2020) and Schraff (2020), also point to the possible endogenous character of trust to the Covid-19 crisis. However, our analysis seems to be free of this endogeneity problem for two reasons: $i$ - we consider, as previously stated, the pre-Covid trust; $i i$ Covid-19 is similar to a natural experiment that hit the world mainly in 2020, and it seems unlikely that the Covid crisis of the 2020-2021 period could influence the state of trust between 2018 and 2019 given the context-dependent character of responses to trust questions. Therefore, we can present the trust used in this work as exogenous to the Covid-19 crisis. Putting these two arguments together in addition to control variables used to address potential omitted relevant variable biases, we can consider our model estimated by Ordinary Least Squares (OLS) able to capture the causal effect of trust.

\section{Results}

Our baseline results are presented in Table 2. The first column presents the effect of trust on Covid-19 cases per million population. The results reveal a negative and significant effect of trust on the number of Covid-19 cases. More precisely, a one percent increase in trust decreases the number of infections per million population by 327.15. Relative to the sample mean, this result shows that a one percent increase in trust decreases the number of cases per million population by almost $2 \%$. Finally, it is important

14. See ://www.statista.com/statistics/1107643/covid-19-trust-government-france/ 
medRxiv preprint doi: https://doi.org/10.1101/2021.07.10.21260297; this version posted July 14,2021 . The copyright holder for this preprint (which was not certified by peer review) is the author/funder, who has granted medRxiv a license to display the preprint in perpetuity.

to note that all our statistically significant control variables have the expected sign.

In column [2], we analyze the effect of trust on Covid-19 deaths per million population. The result shows a negative effect of trust on the Covid-19 related deaths. The magnitude of the coefficient reveals that a one percent increase in trust decreases the number of deaths per million population by 14.16. Relative to the sample mean, this result indicates a decrease of almost $3 \%$ for a one percent increase in trust. As previously reported, all our control variables have the expected sign. ${ }^{15}$

In sum, results in this section show that trust determines sound management of the pandemic. More concretely, on average, a country can experience a decrease in the number of cases and deaths per million population of $2 \%$ and $3 \%$ respectively for a one percent increase in the trust of citizens in their government.

Table 2 - Covid-19 crisis management and trust

[1] [2]

Covid cases Covid deaths

Trust in government

$-327.148^{* *}$

$-14.166^{* * * *}$

(136.3815)

Population density

19.269

$0.558^{*}$

(12.2138)

$(0.3104)$

Public expenditure

156.269

3.839

$(162.0462)$

Hospital beds per thousand $-1402.661^{* *}$

$-38.434^{* *}$

(571.7117)

Trade openness

145.250 ***

$2.973 * * *$

GDP per capita growth

$-1345.276$

$-85.550 * *$

(1421.9632)

Observations

41

41

R-squared

0.402

0.496

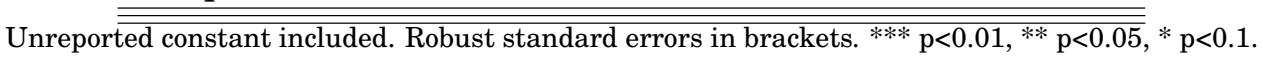

15. Based on conclusions of Table 1 on the one hand and, on the other hand, for a better appreciation of these results, we evaluate the effect according to the level of trust. In other words, we compare countries with high trust to countries with low trust. To do so, we compute a dummy variable that takes 1 (high trust countries) if country $i$ 's trust is above the sample median and 0 (low trust countries) for countries whose trust is below the sample median and re-estimate our baseline model by replacing trust with this new (dummy) variable. The results, available upon request, show that high-trust countries exhibit lower numbers of cases and deaths per million population ( 8143.90 and 358.38 respectively) compared to lowtrust countries. Applied to France, which has a population of 67.06 million based on 2020 estimations (see https: / / www. insee.fr/fr/statistiques / 4277615 ? sommaire=4318291), this would amount to a reduction in the number of cases and deaths of 546129.93 and 24032.96 respectively. 
medRxiv preprint doi: https://doi.org/10.1101/2021.07.10.21260297; this version posted July 14, 2021. The copyright holder for this preprint (which was not certified by peer review) is the author/funder, who has granted medRxiv a license to display the preprint in perpetuity.

\section{Robustness}

In this section, we mainly test the robustness of our results to alternative samples, additional controls, alternative definitions of the dependent and interest variables.

\subsection{Alternative sample}

We start our robustness exercise by testing the sensitivity of our results to sample selection. Four modifications of the sample are performed. First, we exclude March 1, 2020 to May 1, 2020 in computing the average number of cases and deaths. Indeed, this period is marked in many countries by stringent measures such as strict lockdown, which may overestimate the effect of trust on the pandemic management. Second, we take into account outliers by excluding the top (bottom) 5\% of countries with high (low) trust in their government. ${ }^{16}$ Finally, in order to reduce the heterogeneity ${ }^{17}$ that may characterize the countries in our sample, we exclude the non-OECD countries to have a more homogeneous sample at least in terms of income levels. Results reported in columns [1]-[4] of Table 3 for the number of cases and deaths produce similar results to our baseline findings. In other words, our results are neither driven by strict lockdown measures nor outliers and income disparities.

\subsection{Potential omitted variables}

We continue our robustness exercise by testing the sensitivity of our results to additional control variables. Based on the literature of the Covid-19 pandemic and trust, we include four groups of control variables. The first group includes a range of health policy variables and risk factors, including test policy (share of the population tested), positive rate, reproduction rate, share of the population vaccinated (vaccinations), the proportion of population above 65 years (above $65 \mathrm{yrs}$ ), the cardiovascular death rate (cardio. death), diabetes prevalence (diabetes), the share of the smoking population (smoke), and stringency index. The second group includes institutional variables such as democ-

16. The top 5\% high trust countries are Luxembourg, New Zealand, Switzerland and the bottom 5\% low trust countries are Italy and Latvia

17. Another way to reduce cross-country heterogeneity (and subsequently have a relatively normal distribution of variables) is to use a log-transformation for the crisis management variables, notably the number of cases and deaths. Results of this transformation, available on request, show a negative and significant effect of trust in government on the logarithm of the number of cases and deaths. Specifically, a one percent increase in citizens' trust in their government reduces the number of cases and deaths by $3 \%$ and $5 \%$ respectively. 
medRxiv preprint doi: https://doi.org/10.1101/2021.07.10.21260297; this version posted July 14, 2021. The copyright holder for this preprint (which was not certified by peer review) is the author/funder, who has granted medRxiv a license to display the preprint in perpetuity.

Table 3 - Alternative sample

\begin{tabular}{|c|c|c|c|c|}
\hline Covid cases & $\begin{array}{c}{[1]} \\
\text { Covid cases without March } 1 \text { to May } 1\end{array}$ & $\begin{array}{c}{[2]} \\
\text { Excluding top 5\% trust }\end{array}$ & $\begin{array}{c}{[3]} \\
\text { Excluding bottom 5\% trust }\end{array}$ & $\begin{array}{c}{[4]} \\
\text { Drop non-OECD countries }\end{array}$ \\
\hline Trust in government & $\begin{array}{r}-353.296 * * \\
(147.5550)\end{array}$ & $\begin{array}{c}-396.687 * * * * \\
(130.0799)\end{array}$ & $\begin{array}{l}-386.047^{* *} \\
(162.1094)\end{array}$ & $\begin{array}{l}-268.166^{*} \\
(140.8277)\end{array}$ \\
\hline Main controls & Yes & Yes & Yes & Yes \\
\hline $\begin{array}{l}\text { Observations } \\
\text { R-squared }\end{array}$ & $\begin{array}{c}41 \\
0.402 \\
\end{array}$ & $\begin{array}{c}38 \\
0.383 \\
\end{array}$ & $\begin{array}{c}39 \\
0.427 \\
\end{array}$ & $\begin{array}{c}33 \\
0.452 \\
\end{array}$ \\
\hline Covid deaths & $\begin{array}{l}{[1]} \\
\text { Covid deaths without March } 1 \text { to May } 1\end{array}$ & $\begin{array}{c}{[2]} \\
\text { Excluding top 5\% trust }\end{array}$ & $\begin{array}{c}{[3]} \\
\text { Excluding bottom 5\% trust }\end{array}$ & $\begin{array}{c}{[4]} \\
\text { Drop non-OECD countries }\end{array}$ \\
\hline Trust in government & $\begin{array}{c}-14.875^{* * * *} \\
(3.6265)\end{array}$ & $\begin{array}{l}-16.230 * * * \\
(3.1499)\end{array}$ & $\begin{array}{l}-14.813^{* * *} \\
(4.1200)\end{array}$ & $\begin{array}{l}-14.039 * * * \\
(3.6280)\end{array}$ \\
\hline Main controls & Yes & Yes & Yes & Yes \\
\hline $\begin{array}{l}\text { Observations } \\
\text { R-squared }\end{array}$ & $\begin{array}{c}41 \\
0.493\end{array}$ & $\begin{array}{c}38 \\
0.547\end{array}$ & $\begin{array}{c}39 \\
0.474\end{array}$ & $\begin{array}{c}33 \\
0.492\end{array}$ \\
\hline
\end{tabular}

racy, government fractionalization (gov. frac.), years left in current term (yrs left in cur. term), government polarization (gov. polarization), and central bank independence (central bank ind.). The third group includes real economy and demographic variables such as inflation, unemployment, urbanization, level of development (level dev.), debt ratings (ratings), inequality, financial openness, and human capital. The fourth group includes social, migration, and health variables such as cultural tightness-looseness (tightness), the share of people adhering to religion (religion), ${ }^{18}$ national pride, migrant stock (percent migrants), and pre-pandemic all-cause mortality (death). Detailed descriptions of these variables can be found in the Appendix. Results reported in columns [1]-[27] of Tables 4 and 5 show that including these variables yields similar results to our initial findings.

\subsection{Alternative definitions of the dependent variable}

In this section, we take a closer look at the definition of our dependent variables by changing the number of cases and deaths per million population (disease prevalence) in our model to new cases per million population (disease incidence), new deaths per million population (disease incidence), hospitalized patients per million population (hosp. patients), Intensive Care Unit (ICU) patients per million population, excess mortality (P-scores), and Covid Performance Index (CPI). The results are compiled in Table 6.

18. Religion affiliation may play a significant role in trust and values, as pointed out by Guiso et al., 2006 and Ortiz-Ospina and Roser, 2016. 
medRxiv preprint doi: https://doi.org/10.1101/2021.07.10.21260297; this version posted July 14, 2021. The copyright holder for this preprint (which was not certified by peer review) is the author/funder, who has granted medRxiv a license to display the preprint in perpetuity.

It is made available under a CC-BY-NC-ND 4.0 International license .

Table 4 - Potential omitted variables

\begin{tabular}{|c|c|c|c|c|c|c|c|c|c|}
\hline Covid cases & $\begin{array}{c}{[1]} \\
\text { Test policy } \\
\end{array}$ & $\begin{array}{c}{[2]} \\
\text { Positive rate }\end{array}$ & $\begin{array}{c}{[3]} \\
\text { Reproduction rate } \\
\end{array}$ & $\begin{array}{c}{[4]} \\
\text { Vaccinations }\end{array}$ & $\begin{array}{c}{[5]} \\
\text { Above } 65 \text { years }\end{array}$ & $\begin{array}{c}{[6]} \\
\text { Cardio. death } \\
\end{array}$ & $\begin{array}{c}7] \\
\text { Diabetes } \\
\end{array}$ & $\begin{array}{c}{[8]} \\
\text { Smoke } \\
\end{array}$ & $\begin{array}{c}{[9]} \\
\text { Stringency index }\end{array}$ \\
\hline Trust in government & $\begin{array}{l}-286.378 * * \\
(133.2645)\end{array}$ & $\begin{array}{l}-268.009 * * \\
(110.4961)\end{array}$ & $\begin{array}{l}-307.753^{* *} \\
(128.4061)\end{array}$ & $\begin{array}{l}-323.169 * * \\
(130.2480)\end{array}$ & $\begin{array}{l}-327.573 * * \\
(139.4625)\end{array}$ & $\begin{array}{l}-300.184 * * \\
(138.2220)\end{array}$ & $\begin{array}{l}-329.921 * * \\
(139.2106)\end{array}$ & $\begin{array}{l}-277.433 * * \\
(129.8833)\end{array}$ & $\begin{array}{l}-289.425^{* *} \\
(138.1130)\end{array}$ \\
\hline $\begin{array}{l}\text { Main controls } \\
\text { Observations } \\
\text { R-squared }\end{array}$ & $\begin{array}{c}\text { Yes } \\
38 \\
0.463 \\
\end{array}$ & $\begin{array}{c}\text { Yes } \\
41 \\
0.493 \\
\end{array}$ & $\begin{array}{c}\text { Yes } \\
41 \\
0.439 \\
\end{array}$ & $\begin{array}{c}\text { Yes } \\
41 \\
0.431 \\
\end{array}$ & $\begin{array}{c}\text { Yes } \\
41 \\
0.403 \\
\end{array}$ & $\begin{array}{c}\text { Yes } \\
41 \\
0.412 \\
\end{array}$ & $\begin{array}{c}\text { Yes } \\
41 \\
0.427 \\
\end{array}$ & $\begin{array}{c}\text { Yes } \\
41 \\
0.430 \\
\end{array}$ & $\begin{array}{c}\text { Yes } \\
41 \\
0.428 \\
\end{array}$ \\
\hline & $\begin{array}{c}{[10]} \\
\text { Democracy }\end{array}$ & $\begin{array}{c}{[11]} \\
\text { Gov. Frac }\end{array}$ & $\begin{array}{c}{[12]} \\
\text { Yrs Left in Cur. Term }\end{array}$ & $\begin{array}{c}{[13]} \\
\text { Gov. polarization }\end{array}$ & $\begin{array}{l}{[14]} \\
\text { Central bank ind. }\end{array}$ & $\begin{array}{c}{[15]} \\
\text { Inflation } \\
\end{array}$ & $\begin{array}{c}{[16]} \\
\text { Unemployment }\end{array}$ & $\begin{array}{c}{[17]} \\
\text { Urbanization } \\
\end{array}$ & $\begin{array}{c}{[18]} \\
\text { Level dev. }\end{array}$ \\
\hline Trust in government & $\begin{array}{l}-320.072^{* * *} \\
(139.4744)\end{array}$ & $\begin{array}{l}-324.579 * * \\
(137.1994)\end{array}$ & $\begin{array}{l}-334.965^{* *} \\
(146.5897)\end{array}$ & $\begin{array}{l}-328.402 * * \\
(129.4040)\end{array}$ & $\begin{array}{l}-315.257 * * \\
(140.6236)\end{array}$ & $\begin{array}{l}-316.017 * * \\
(136.6651)\end{array}$ & $\begin{array}{l}-340.672 * * \\
(141.3791)\end{array}$ & $\begin{array}{l}-311.308^{* *} \\
(135.5310)\end{array}$ & $\begin{array}{l}-308.404 * * \\
(135.4851)\end{array}$ \\
\hline $\begin{array}{l}\text { Main controls } \\
\text { Observations } \\
\text { R-squared }\end{array}$ & $\begin{array}{c}\text { Yes } \\
40 \\
0.406 \\
\end{array}$ & $\begin{array}{c}\text { Yes } \\
41 \\
0.405\end{array}$ & $\begin{array}{c}\text { Yes } \\
40 \\
0.413 \\
\end{array}$ & $\begin{array}{c}\text { Yes } \\
40 \\
0.407 \\
\end{array}$ & $\begin{array}{c}\text { Yes } \\
41 \\
0.405 \\
\end{array}$ & $\begin{array}{c}\text { Yes } \\
41 \\
0.417 \\
\end{array}$ & $\begin{array}{c}\text { Yes } \\
41 \\
0.404 \\
\end{array}$ & $\begin{array}{c}\text { Yes } \\
41 \\
0.415 \\
\end{array}$ & $\begin{array}{c}\text { Yes } \\
41 \\
0.409 \\
\end{array}$ \\
\hline & $\begin{array}{c}{[19]} \\
\text { Ratings }\end{array}$ & $\begin{array}{c}{[20]} \\
\text { Inequality }\end{array}$ & $\begin{array}{c}{[21]} \\
\text { Financial openness } \\
\end{array}$ & $\begin{array}{c}{[22]} \\
\text { Human capital }\end{array}$ & $\begin{array}{c}{[23]} \\
\text { Tightness } \\
\end{array}$ & $\begin{array}{c}{[24]} \\
\text { Religion } \\
\end{array}$ & $\begin{array}{c}{[25]} \\
\text { National pride } \\
\end{array}$ & $\begin{array}{c}{[26]} \\
\text { Percent migrants }\end{array}$ & $\begin{array}{c}{[27]} \\
\text { Death }\end{array}$ \\
\hline Trust in government & $\begin{array}{l}-325.882 * * \\
(146.2109)\end{array}$ & $\begin{array}{l}-317.634^{* *} \\
(143.1444)\end{array}$ & $\begin{array}{l}-323.690 * * \\
(138.7517)\end{array}$ & $\begin{array}{l}-340.439 * * \\
(141.8741)\end{array}$ & $\begin{array}{l}-344.532 * * \\
(147.9936)\end{array}$ & $\begin{array}{l}-326.595 * * \\
(138.5136)\end{array}$ & $\begin{array}{c}-353.454 * * * \\
(128.7271)\end{array}$ & $\begin{array}{l}-339.451^{* *} \\
(141.9612)\end{array}$ & $\begin{array}{l}-309.100^{* * *} \\
(142.6026)\end{array}$ \\
\hline $\begin{array}{l}\text { Main controls } \\
\text { Observations } \\
\text { R-squared }\end{array}$ & $\begin{array}{c}\text { Yes } \\
41 \\
0.402 \\
\end{array}$ & $\begin{array}{c}\text { Yes } \\
41 \\
0.404 \\
\end{array}$ & $\begin{array}{c}\text { Yes } \\
40 \\
0.346\end{array}$ & $\begin{array}{c}\text { Yes } \\
41 \\
0.406\end{array}$ & $\begin{array}{c}\text { Yes } \\
41 \\
0.406\end{array}$ & $\begin{array}{c}\text { Yes } \\
41 \\
0.406\end{array}$ & $\begin{array}{c}\text { Yes } \\
40 \\
0.367\end{array}$ & $\begin{array}{c}\text { Yes } \\
41 \\
0.403\end{array}$ & $\begin{array}{c}\text { Yes } \\
41 \\
0.406\end{array}$ \\
\hline
\end{tabular}

Unreported constant included. Robust standard errors in brackets. ${ }^{* * *} \mathrm{p}<0.01,{ }^{* *} \mathrm{p}<0.05,{ }^{*} \mathrm{p}<0.1$. Main controls are those in Table 2.

Table 5 - Potential omitted variables

\begin{tabular}{|c|c|c|c|c|c|c|c|c|c|}
\hline Covid deaths & $\begin{array}{c}{[1]} \\
\text { Test policy } \\
\end{array}$ & $\begin{array}{c}{[2]} \\
\text { Positive rate }\end{array}$ & $\begin{array}{c}{[3]} \\
\text { Reproduction rate }\end{array}$ & $\begin{array}{c}{[4]} \\
\text { Vaccinations } \\
\end{array}$ & $\begin{array}{c}{[5]} \\
\text { Above } 65 \text { years } \\
\end{array}$ & $\begin{array}{c}{[6]} \\
\text { Cardio. death } \\
\end{array}$ & $\begin{array}{c}{[7]} \\
\text { Diabetes } \\
\end{array}$ & $\begin{array}{c}{[8]} \\
\text { Smoke } \\
\end{array}$ & $\begin{array}{c}{[9]} \\
\text { Stringency index } \\
\end{array}$ \\
\hline Trust in government & $\begin{array}{c}-13.817 * * * \\
(3.3049)\end{array}$ & $\begin{array}{c}-12.445^{* * * *} \\
(2.8427)\end{array}$ & $\begin{array}{l}-13.065^{* * * *} \\
(2.5418)\end{array}$ & $\begin{array}{l}-14.068^{* * * *} \\
(3.1250)\end{array}$ & $\begin{array}{l}-14.162^{* * * *} \\
(3.4543)\end{array}$ & $\begin{array}{l}-13.686^{* * * *} \\
(3.4908)\end{array}$ & $\begin{array}{l}-14.225^{* * * *} \\
(3.5304)\end{array}$ & $\begin{array}{l}-13.482^{* * * *} \\
(3.2730)\end{array}$ & $\begin{array}{l}-13.299 * * * \\
(3.4264)\end{array}$ \\
\hline $\begin{array}{l}\text { Main controls } \\
\text { Observations } \\
\text { R-squared }\end{array}$ & $\begin{array}{c}\text { Yes } \\
38 \\
0.521 \\
\end{array}$ & $\begin{array}{c}\text { Yes } \\
41 \\
0.610 \\
\end{array}$ & $\begin{array}{c}\text { Yes } \\
41 \\
0.668 \\
\end{array}$ & $\begin{array}{c}\text { Yes } \\
41 \\
0.522 \\
\end{array}$ & $\begin{array}{c}\text { Yes } \\
41 \\
0.496 \\
\end{array}$ & $\begin{array}{c}\text { Yes } \\
41 \\
0.501\end{array}$ & $\begin{array}{c}\text { Yes } \\
41 \\
0.513 \\
\end{array}$ & $\begin{array}{c}\text { Yes } \\
41 \\
0.504 \\
\end{array}$ & $\begin{array}{c}\text { Yes } \\
41 \\
0.517 \\
\end{array}$ \\
\hline & $\begin{array}{c}{[10]} \\
\text { Democracy }\end{array}$ & $\begin{array}{c}{[11]} \\
\text { Gov. Frac } \\
\end{array}$ & $\begin{array}{c}{[12]} \\
\text { Yrs Left in Cur. Term }\end{array}$ & $\begin{array}{c}{[13]} \\
\text { Gov. polarization }\end{array}$ & $\begin{array}{c}{[14]} \\
\text { Central bank ind. }\end{array}$ & $\begin{array}{c}{[15]} \\
\text { Inflation } \\
\end{array}$ & $\begin{array}{c}{[16]} \\
\text { Unemployment }\end{array}$ & $\begin{array}{c}{[17]} \\
\text { Urbanization } \\
\end{array}$ & $\begin{array}{c}{[18]} \\
\text { Level dev. }\end{array}$ \\
\hline Trust in government & $\begin{array}{c}-13.491^{* * * *} \\
(3.4644)\end{array}$ & $\begin{array}{l}-14.372^{* * * *} \\
(3.8059)\end{array}$ & $\begin{array}{c}-13.831^{* * * *} \\
(3.5120)\end{array}$ & $\begin{array}{l}-13.697 * * * \\
(3.2508)\end{array}$ & $\begin{array}{c}-13.638^{* * * *} \\
(3.4933)\end{array}$ & $\begin{array}{c}-14.024 * * * \\
(3.4470)\end{array}$ & $\begin{array}{l}-14.119 * * * \\
(3.3381)\end{array}$ & $\begin{array}{l}-13.703^{* * * *} \\
(3.5375)\end{array}$ & $\begin{array}{l}-13.325^{* * * *} \\
(3.5215)\end{array}$ \\
\hline $\begin{array}{l}\text { Main controls } \\
\text { Observations } \\
\text { R-squared }\end{array}$ & $\begin{array}{l}\text { Yes } \\
40 \\
0.508\end{array}$ & $\begin{array}{c}\text { Yes } \\
41 \\
0.526 \\
\end{array}$ & $\begin{array}{c}\text { Yes } \\
40 \\
0.502\end{array}$ & $\begin{array}{c}\text { Yes } \\
40 \\
0.496 \\
\end{array}$ & $\begin{array}{c}\text { Yes } \\
41 \\
0.503\end{array}$ & $\begin{array}{c}\text { Yes } \\
41 \\
0.500 \\
\end{array}$ & $\begin{array}{c}\text { Yes } \\
41 \\
0.496 \\
\end{array}$ & $\begin{array}{c}\text { Yes } \\
41 \\
0.512 \\
\end{array}$ & $\begin{array}{c}\text { Yes } \\
41 \\
0.517 \\
\end{array}$ \\
\hline & $\begin{array}{c}\text { [19] } \\
\text { Ratings }\end{array}$ & $\begin{array}{c}{[20]} \\
\text { Inequality }\end{array}$ & $\begin{array}{c}{[21]} \\
\text { Financial openness } \\
\end{array}$ & $\begin{array}{c}{[22]} \\
\text { Human capital }\end{array}$ & $\begin{array}{c}{[23]} \\
\text { Tightness } \\
\end{array}$ & $\begin{array}{c}{[24]} \\
\text { Religion } \\
\end{array}$ & $\begin{array}{c}{[25]} \\
\text { National pride } \\
\end{array}$ & $\begin{array}{c}{[26]} \\
\text { Percent migrants }\end{array}$ & $\begin{array}{c}{[27]} \\
\text { Death }\end{array}$ \\
\hline Trust in government & $\begin{array}{c}-15.474 * * * \\
(3.3374)\end{array}$ & $\begin{array}{l}-13.848^{* * * *} \\
(3.3517)\end{array}$ & $\begin{array}{l}-14.223 * * * \\
(3.2295)\end{array}$ & $\begin{array}{c}-13.820 * * * \\
(3.3645)\end{array}$ & $\begin{array}{l}-14.221^{* * * *} \\
(3.5113)\end{array}$ & $\begin{array}{c}-14.163 * * * \\
(3.4429)\end{array}$ & $\begin{array}{c}-14.808^{* * * *} \\
(2.8443)\end{array}$ & $\begin{array}{c}-12.804 * * * \\
(3.7413)\end{array}$ & $\begin{array}{l}-13.088 * * * * \\
(3.5033)\end{array}$ \\
\hline $\begin{array}{l}\text { Main controls } \\
\text { Observations } \\
\text { R-squared }\end{array}$ & $\begin{array}{c}\text { Yes } \\
41 \\
0.508\end{array}$ & $\begin{array}{c}\text { Yes } \\
41 \\
0.498\end{array}$ & $\begin{array}{c}\text { Yes } \\
40 \\
0.517\end{array}$ & $\begin{array}{c}\text { Yes } \\
41 \\
0.500\end{array}$ & $\begin{array}{c}\text { Yes } \\
41 \\
0.496\end{array}$ & $\begin{array}{c}\text { Yes } \\
41 \\
0.496\end{array}$ & $\begin{array}{c}\text { Yes } \\
40 \\
0.534\end{array}$ & $\begin{array}{c}\text { Yes } \\
41 \\
0.513\end{array}$ & $\begin{array}{c}\text { Yes } \\
41 \\
0.513\end{array}$ \\
\hline
\end{tabular}

Unreported constant included. Robust standard errors in brackets. ${ }^{* * *} \mathrm{p}<0.01,{ }^{* *} \mathrm{p}<0.05,{ }^{*} \mathrm{p}<0.1$. Main

controls are those in Table 2. 
medRxiv preprint doi: https://doi.org/10.1101/2021.07.10.21260297; this version posted July 14,2021 . The copyright holder for this preprint (which was not certified by peer review) is the author/funder, who has granted medRxiv a license to display the preprint in perpetuity.

It is made available under a CC-BY-NC-ND 4.0 International license.

They reveal that a high level of trust decreases the number of new cases and deaths and the number of hospitalized patients (columns [1]-[3]). The number of ICU patients also decreases (column [4]). A closer look at the magnitude of the coefficient shows that one standard deviation increase in trust decreases the number of ICU patients by 14.92 percentage points, i.e., a reduction of the unconditional mean by $60.7 \%$. In addition, excess mortality is also negatively associated with trust in government (column [5]). Specifically, one standard deviation increase in trust decreases the excess mortality during the Covid-19 crisis by 3.78 percentage points, representing a decrease in the unconditional mean excess mortality by $32 \%$. Finally, results regarding the effect of trust on Covid-19 performance show a positive and significant effect (column [6]). The size of the coefficient means that one standard deviation increase in trust increases the performance of the Covid-19 by 18.28 percentage points or an increase in the unconditional mean by $39 \%$. In light of these results, we can easily say that changing the crisis management measures does not alter our conclusions.

Table 6 - Alternative definition of the dependent variable

\begin{tabular}{|c|c|c|c|c|c|c|}
\hline & $\begin{array}{c}{[1]} \\
\text { New cases }\end{array}$ & $\begin{array}{c}{[2]} \\
\text { New deaths }\end{array}$ & $\begin{array}{c}{[3]} \\
\text { Hosp. patients }\end{array}$ & $\begin{array}{c}{[4]} \\
\text { ICU patients }\end{array}$ & $\begin{array}{c}{[5]} \\
\text { Excess mortality }\end{array}$ & $\begin{array}{c}{[6]} \\
\text { CPI }\end{array}$ \\
\hline Trust in government & $\begin{array}{l}-2.293 * * \\
(0.9348)\end{array}$ & $\begin{array}{c}-0.089 * * * \\
(0.0188)\end{array}$ & $\begin{array}{c}-4.205^{* * * *} \\
(1.3647)\end{array}$ & $\begin{array}{c}-0.653^{* * * *} \\
(0.2011)\end{array}$ & $\begin{array}{c}-0.381 * * * \\
(0.0971)\end{array}$ & $\begin{array}{c}0.427^{*} \\
(0.2396)\end{array}$ \\
\hline Main controls & Yes & Yes & Yes & Yes & Yes & Yes \\
\hline Obser & 41 & 41 & 26 & 20 & 39 & 37 \\
\hline $\mathrm{R}$-squared & 0.426 & 0.467 & 0.631 & 0.662 & 0.433 & 0.431 \\
\hline
\end{tabular}

Unreported constant included. Robust standard errors in brackets. ${ }^{* * *} \mathrm{p}<0.01,{ }^{* *} \mathrm{p}<0.05,{ }^{*} \mathrm{p}<0.1$. Main controls are those in Table 2.

\subsection{Alternative definition of interest variable}

Finally, we test the robustness of our results to alternative definitions of the interest variable in two ways.

First, instead of using the 2018-2019 average, we choose the average over the period 2006 (the latest year in our database) to 2019, the average over 2006-2019 without the Global Financial Crisis (GFC) period to purge our measure of the potential effect of the financial crisis on trust. Finally, and in contrast to previous measures, we take 2019 trust observations instead of average over any period. The results of these tests presented in columns [1]-[6] of Table 7 show negative and significant effects of the three 
medRxiv preprint doi: https://doi.org/10.1101/2021.07.10.21260297; this version posted July 14, 2021. The copyright holder for this preprint (which was not certified by peer review) is the author/funder, who has granted medRxiv a license to display the preprint in perpetuity. It is made available under a CC-BY-NC-ND 4.0 International license.

measures of trust on cases (deaths) per million population, with coefficients close to the baseline model.

Second, we use trust measures from the European Social Survey (ESS) database, which provides survey data on trust in Europe. The survey consists of asking individuals to select between 0 (no trust) and 10 (total trust). For our work, and given the high number of intermediate answers between 0 and 10, it seems impossible to compute the proportion of people who declare trust in institutions as in our baseline model. For this reason, we rely on simple mean values by country of the different responses of the interviewees in Wave 9. The results based on three measures of trust, namely trust in politicians, satisfaction with the national government, and satisfaction with the way democracy works in the country, are presented in Table 7 (columns [7]-[12]) and show signs consistent with the baseline model. Indeed, high levels of these three trust measures are associated with low levels of Covid-19 cases (deaths). However, we must note that the magnitudes of the coefficients are much larger, probably due to the geographical coverage of the database (only in Europe) and to the difference in the scale of the trust variables compared to that used in the baseline model.

Table 7 - Alternative definition of interest variable

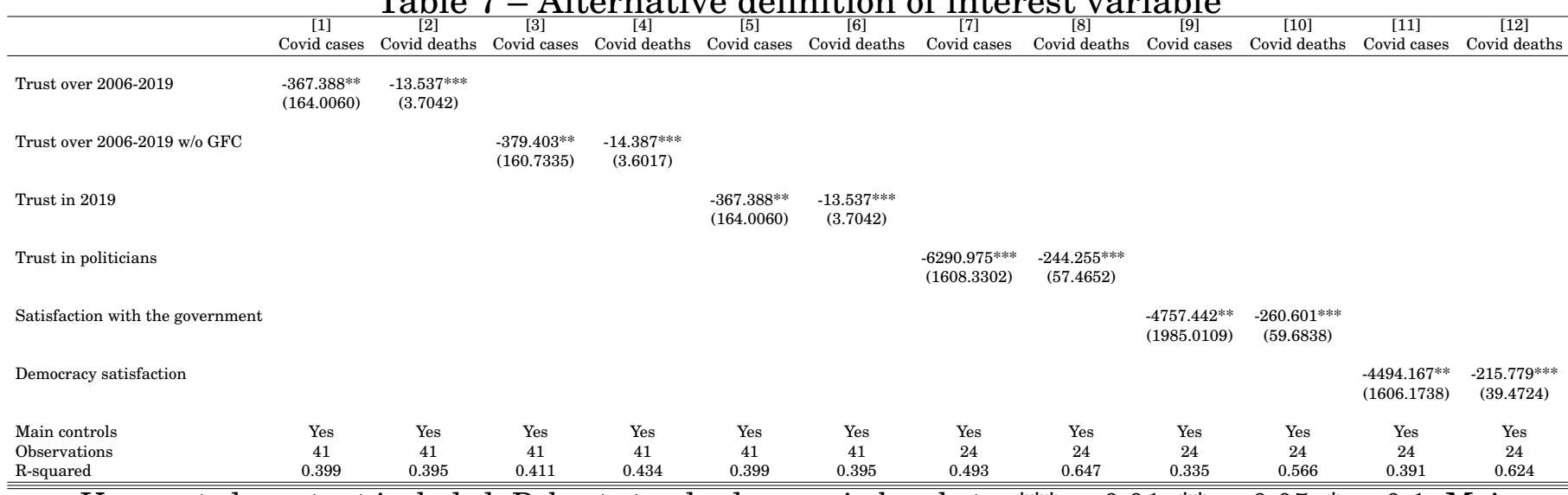

Unreported constant included. Robust standard errors in brackets. *** p<0.01, ** p<0.05, * p<0.1. Main controls are those in Table 2.

\section{Heterogeneity}

Previous results indicate that high trust between population and government favors successful management of the crisis through lower cases and deaths. In this section, we test the sensitivity of these results to the contamination level (cases) and the time dimension. 
medRxiv preprint doi: https://doi.org/10.1101/2021.07.10.21260297; this version posted July 14,2021 . The copyright holder for this preprint (which was not certified by peer review) is the author/funder, who has granted medRxiv a license to display the preprint in perpetuity.

\subsection{The level of contamination}

In this section, we evaluate the sensitivity of our results to the number of cases per million population. To do so, we distinguish the early phase of the pandemic marked by the number of cases below 100 per million population from the late phase characterized by a level of contamination above this threshold. Results presented in column [1] of Table 8 reveal no evidence of trust effect on Covid-19 spread below 100 cases per million population. Concerning the number of deaths (column [2]), we observe a slight decrease with trust. However, beyond 100 cases per million population, the level of trust strongly determines the reduction of contamination and deaths (columns [3]-[4]). This result may be explained by higher compliance to containment measures that characterize hightrust countries once reaching this threshold. ${ }^{19}$

Table 8 - The level of contamination

\begin{tabular}{lcccc}
\hline & {$[1]$} & {$[2]$} & {$[3]$} & {$[4]$} \\
& Cases $<100$ & Cases $<100$ & Cases $>100$ & Cases $>100$ \\
\hline \multirow{3}{*}{ Trust in government } & -0.119 & $-0.014^{* *}$ & $-365.101^{* *}$ & $-14.690^{* * *}$ \\
& $(0.0956)$ & $(0.0059)$ & $(144.5775)$ & $(3.4770)$ \\
& & & & \\
Main controls & Yes & Yes & Yes & Yes \\
Observations & 41 & 34 & 41 & 41 \\
R-squared & 0.155 & 0.274 & 0.387 & 0.491 \\
\hline \hline
\end{tabular}

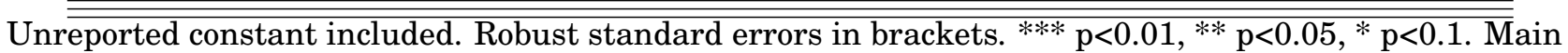
controls are those in Table 2. In columns [1] and [3] ([2] and [4]), the number of cases (deaths) per million population is the dependent variable.

\subsection{Time perspective}

Attitudes of trust and other cultural and institutional traits may surprisingly persist for a long time (Acemoglu et al., 2001; Algan and Cahuc, 2007; Bjørnskov, 2007; Dearmon and Grier, 2009; Tabellini, 2010). Capitalizing on this observation, this section investigates whether the effect of pre-crisis trust is long-lasting or short-lived. In other words, we document whether the effect of trust on crisis management ends in 2020 or

19. It is important to note that below 100 cases per million population, many countries do not implement effective containment measures, which may justify virtually the same pattern of crisis management in this phase of the pandemic, i.e., statistically non-significant effect of trust on the number of cases and a relatively small effect on the number of deaths. In addition, existing literature, including Fotiou and Lagerborg (2021) shows high efficiency of health or containment policies once 100 cases per million of population are reached. 
medRxiv preprint doi: https://doi.org/10.1101/2021.07.10.21260297; this version posted July 14, 2021. The copyright holder for this preprint (which was not certified by peer review) is the author/funder, who has granted medRxiv a license to display the preprint in perpetuity.

keeps going. To do so, we analyze a dynamic effect of trust by assessing its impact on crisis management (number of cases and deaths per million population) in 2020 and 2021. The results presented in Table 9 show that trust influences the number of cases and deaths in both 2020 and 2021. More interestingly, the effect appears to increase over time. In other words, the effect in 2021, although our sample ends on May 26, 2021, already exceeds that found in 2020. In view of these results, it appears consistent with the literature that the effect of trust is more persistent than transitory in dealing with the crisis.

Table 9 - Time perspective

[1] [2]

First year (2020) Covid cases Covid deaths

Trust in government

$-118.700^{* *}$ $-6.814 * * *$ $(50.6428)$

$(2.2891)$

Main controls Yes 41

Observations

0.407

[1]

Second year (January 1, 2021 to May 26, 2021) Covid cases Covid deaths

Trust in government

$-788.930 * *$

$-28.904^{* * * *}$

(338.7875)

(6.6899)

Main controls

Yes

Yes

Observations

41

41

$\mathrm{R}$-squared

0.398

Unreported constant included. Robust standard errors in brackets. ${ }^{* * *} \mathrm{p}<0.01, * * \mathrm{p}<0.05,{ }^{*} \mathrm{p}<0.1$. Main controls are those in Table 2.

\section{Conclusion}

In times when citizens' commitment and responsibility are highly needed, this article documents the effect of pre-Covid trust in government on the pandemic's management. Robust results from various tests, including alternative definitions of the dependent and interest variables, sample alteration, and additional controls, reveal that a high 
medRxiv preprint doi: https://doi.org/10.1101/2021.07.10.21260297; this version posted July 14, 2021. The copyright holder for this preprint (which was not certified by peer review) is the author/funder, who has granted medRxiv a license to display the preprint in perpetuity. It is made available under a CC-BY-NC-ND 4.0 International license .

level of trust improves the Covid-19 crisis management through lower numbers of cases and deaths per million population. Heterogeneity tests performed later show that our results are sensitive to the level of contamination and increase over time. In the light of these different results, this paper calls for further work on trust between governments and citizens to increase compliance with the non-pharmaceutical and pharmaceutical health policies introduced to control the pandemic.

Amid various recovery plans, including the European plans of more than US\$700 billion, the joint US\$50 billion proposals from International Institutions such as the International Monetary Fund (IMF), the World Health Organization (WHO), the International Trade Organization (WTO) and the World Bank and the Paris summit announcements of Tuesday, May 18, this paper calls to take structural differences such as trust into account to achieve more effective management and more synchronized performance for less scattered recovery. In addition to the pandemic crisis, this paper could have important implications for other (current) crises, such as the climate and inequality crisis. Consequently, governments should invest more in trust, which has fallen especially in recent years, in order to increase tax compliance to support redistributive policies and achieve the Sustainable Development Goals (SDGs) on the one hand, and motivate citizens to fully comply with environmental policies on the other hand. 
medRxiv preprint doi: https://doi.org/10.1101/2021.07.10.21260297; this version posted July 14, 2021. The copyright holder for this preprint (which was not certified by peer review) is the author/funder, who has granted medRxiv a license to display the preprint in perpetuity.

\section{References}

Acemoglu, D., Chernozhukov, V., Werning, I., and Whinston, M. D. (2020). Optimal targeted lockdowns in a multi-group SIR model, volume 27102. NBER Working Paper No. 27102.

Acemoglu, D., Johnson, S., and Robinson, J. A. (2001). The colonial origins of comparative development: An empirical investigation. American economic review, 91(5):13691401.

Aktas, M., Gelfand, M. J., and Hanges, P. J. (2016). Cultural tightness-looseness and perceptions of effective leadership. Journal of Cross-Cultural Psychology, 47(2):294309.

Algan, Y. and Cahuc, P. (2007). Social attitudes and economic development: an epidemiological approach. IZA Discussion Papers, No. 2935.

Bargain, O. and Aminjonov, U. (2020). Trust and compliance to public health policies in times of covid-19. Journal of Public Economics, 192:104316.

Barlow, P., van Schalkwyk, M. C., McKee, M., Labonté, R., and Stuckler, D. (2021). Covid-19 and the collapse of global trade: building an effective public health response. The Lancet Planetary Health, 5(2):e102-e107.

Bjørnskov, C. (2007). Determinants of generalized trust: A cross-country comparison. Public choice, 130(1-2):1-21.

Blair, R. A., Morse, B. S., and Tsai, L. L. (2017). Public health and public trust: Survey evidence from the ebola virus disease epidemic in liberia. Social Science \& Medicine, 172:89-97.

Caselli, F., Grigoli, F., Lian, W., and Sandri, D. (2020). The great lockdown: dissecting the economic effects. International Monetary Fund. World Economic Outlook, pages $65-84$.

Chiappini, S., Guirguis, A., John, A., Corkery, J. M., and Schifano, F. (2020). Covid19: the hidden impact on mental health and drug addiction. Frontiers in psychiatry, $11: 767$. 
medRxiv preprint doi: https://doi.org/10.1101/2021.07.10.21260297; this version posted July 14, 2021. The copyright holder for this preprint (which was not certified by peer review) is the author/funder, who has granted medRxiv a license to display the preprint in perpetuity. It is made available under a CC-BY-NC-ND 4.0 International license.

Chinn, M. D. and Ito, H. (2006). What matters for financial development? capital controls, institutions, and interactions. Journal of development economics, 81(1):163-192.

Cowling, B. J., Ali, S. T., Ng, T. W., Tsang, T. K., Li, J. C., Fong, M. W., Liao, Q., Kwan, M. Y., Lee, S. L., Chiu, S. S., et al. (2020). Impact assessment of non-pharmaceutical interventions against coronavirus disease 2019 and influenza in hong kong: an observational study. The Lancet Public Health, 5(5):e279-e288.

Dearmon, J. and Grier, K. (2009). Trust and development. Journal of Economic Behavior \& Organization, 71(2):210-220.

Deb, P., Furceri, D., Ostry, J. D., and Tawk, N. (2020). The effect of containment measures on the COVID-19 pandemic. CEPR Discussion Paper No. DP15086.

Demirguc-Kunt, A., Lokshin, M., and Torre, I. (2020). The sooner, the better: The early economic impact of non-pharmaceutical interventions during the covid-19 pandemic. World Bank Policy Research Working Paper No. 9257.

Devine, D., Gaskell, J., Jennings, W., and Stoker, G. (2020). Trust and the coronavirus pandemic: What are the consequences of and for trust? an early review of the literature. Political Studies Review, page 1478929920948684.

Eriksson, K., Strimling, P., Gelfand, M., Wu, J., Abernathy, J., Akotia, C. S., Aldashev, A., Andersson, P. A., Andrighetto, G., Anum, A., et al. (2021). Perceptions of the appropriate response to norm violation in 57 societies. Nature communications, 12(1):1-11.

Fotiou, A. and Lagerborg, A. (2021). Smart containment: Lessons from countries with past experience. COVID Economics, 74:94-141.

Garriga, A. C. (2016). Central bank independence in the world: A new data set. International Interactions, 42(5):849-868.

Gelfand, M. J., Jackson, J. C., Pan, X., Nau, D., Pieper, D., Denison, E., Dagher, M., Van Lange, P. A., Chiu, C.-Y., and Wang, M. (2021). The relationship between cultural tightness-looseness and covid-19 cases and deaths: a global analysis. The Lancet planetary health, 5(3):e135-e144. 
medRxiv preprint doi: https://doi.org/10.1101/2021.07.10.21260297; this version posted July 14, 2021. The copyright holder for this preprint (which was not certified by peer review) is the author/funder, who has granted medRxiv a license to display the preprint in perpetuity.

Gelfand, M. J., Raver, J. L., Nishii, L., Leslie, L. M., Lun, J., Lim, B. C., Duan, L., Almaliach, A., Ang, S., Arnadottir, J., et al. (2011). Differences between tight and loose cultures: A 33-nation study. science, 332(6033):1100-1104.

Guiso, L., Sapienza, P., and Zingales, L. (2006). Does culture affect economic outcomes? Journal of Economic perspectives, 20(2):23-48.

Hannah Ritchie, Esteban Ortiz-Ospina, D. B. E. M. J. H. B. M. C. G. C. A. L. R.G. and Roser, M. (2020). Coronavirus pandemic (covid-19). Our World in Data. https://ourworldindata.org/coronavirus.

Holman, E. A., Thompson, R. R., Garfin, D. R., and Silver, R. C. (2020). The unfolding covid-19 pandemic: A probability-based, nationally representative study of mental health in the united states. Science advances, 6(42):eabd5390.

Hosny, A. (2021). The Sooner (and the Smarter), the Better: COVID-19 Containment Measures and Fiscal Responses. IMF Working Paper No. 21/65.

Jennings, W. (2020). Covid-19 and the 'rally-round-the flag'effect, uk in a changing europe. Available at: https://ukandeu.ac.uk/covid-19-and-the-rally-round-the-flageffect /.

Keefer, P., Scartascini, C., and Vlaicu, R. (2021). Trust, populism, and the quality of government. The Oxford Handbook of the Quality of Government, page 249.

Kola, L. (2020). Global mental health and covid-19. The Lancet Psychiatry, 7(8):655-657.

Kose, M. A., Kurlat, S., Ohnsorge, F., and Sugawara, N. (2017). A cross-country database of fiscal space. Policy Research Working Paper 8157, World Bank, Washington, DC.

OECD (2013). Trust in government, policy effectiveness and the governance agenda. In Government at a Glance 2013, OECD Publishing, Paris. Available at https://doi.org/10.1787/gov_glance-2013-6-en.

OECD (2021). Trust in government (indicator). doi: 10.1787/1de9675e-en (Accessed on 26 May 2021).

Ortiz-Ospina, E. and Roser, M. (2016). Trust. Our World in Data. https://ourworldindata.org/trust. 
medRxiv preprint doi: https://doi.org/10.1101/2021.07.10.21260297; this version posted July 14, 2021. The copyright holder for this preprint (which was not certified by peer review) is the author/funder, who has granted medRxiv a license to display the preprint in perpetuity.

Pagliaro, S., Sacchi, S., Pacilli, M. G., Brambilla, M., Lionetti, F., Bettache, K., Bianchi, M., Biella, M., Bonnot, V., Boza, M., et al. (2021). Trust predicts covid-19 prescribed and discretionary behavioral intentions in 23 countries. PloS one, 16(3):e0248334.

Panchal, N., Kamal, R., Orgera, K., Cox, C., Garfield, R., Hamel, L., and Chidambaram, P. (2020). The implications of covid-19 for mental health and substance use. Kaiser family foundation.

Schaltegger, C. A. and Torgler, B. (2005). Trust in government and public debt: an empirical analysis. In Proceedings. Annual Conference on Taxation and Minutes of the Annual Meeting of the National Tax Association, volume 98, pages 217-222.

Schraff, D. (2020). Political trust during the covid-19 pandemic: Rally around the flag or lockdown effects? European journal of political research.

Silverio-Murillo, A., Hoehn-Velasco, L., Tirado, A. R., and de la Miyar, J. R. B. (2021). Covid-19 blues: Lockdowns and mental health-related google searches in latin america. Social Science \& Medicine, page 114040.

$\mathrm{Su}, \mathrm{Z}$., Ye, Y., He, J., and Huang, W. (2016). Constructed hierarchical government trust in china: Formation mechanism and political effects. Pacific Affairs, 89(4):771-794.

Tabellini, G. (2010). Culture and institutions: economic development in the regions of europe. Journal of the European Economic association, 8(4):677-716.

Teorell, J., Dahlberg, S., Holmberg, S., Rothstein, B., Alvarado Pachon, N., and Axelsson, S. (2020). The Quality of Government Standard Dataset, version Jan20. University of Gothenburg. The Quality of Government Institute. doi = 10.18157/qogstdjan20, url = http://www.qog.pol.gu.se.

Woskie, L. R. and Fallah, M. P. (2019). Overcoming distrust to deliver universal health coverage: lessons from ebola. $b m j, 366$.

Yaqub, O., Castle-Clarke, S., Sevdalis, N., and Chataway, J. (2014). Attitudes to vaccination: a critical review. Social science \& medicine, 112:1-11. 
medRxiv preprint doi: https://doi.org/10.1101/2021.07.10.21260297; this version posted July 14, 2021. The copyright holder for this preprint (which was not certified by peer review) is the author/funder, who has granted medRxiv a license to display the preprint in perpetuity. It is made available under a CC-BY-NC-ND 4.0 International license .

\section{Appendix}

Table 10 - Descriptive statistics of main variables

\begin{tabular}{|c|c|c|c|c|c|}
\hline Variable & Obs & Mean & Std. Dev. & Min & $\operatorname{Max}$ \\
\hline Total cases per million & 41 & 20543.71 & 11637.1 & 377.94 & 47874.47 \\
\hline Total deaths per million & 41 & 475.083 & 303.025 & 4.758 & 1211.676 \\
\hline New cases per million & 41 & 137.865 & 79.056 & 1.222 & 343.45 \\
\hline New deaths per million & 41 & 2.819 & 1.774 & 0.013 & 7.007 \\
\hline ICU patients per million & 20 & 26.93 & 13.589 & 4.926 & 50.683 \\
\hline Hosp. patients per million & 26 & 172.245 & 110.269 & 19.837 & 451.521 \\
\hline Covid excess mortality & 39 & 12.204 & 10.871 & -3.057 & 55.672 \\
\hline Covid Performance Index & 37 & 47.262 & 19.876 & 6.3 & 93 \\
\hline Trust in government & 41 & 45.167 & 14.555 & 21.428 & 82.83 \\
\hline Trust in politicians & 24 & 5.554 & 0.992 & 4.266 & 7.536 \\
\hline Satisfaction with the government & 24 & 3.897 & 0.921 & 2.552 & 5.385 \\
\hline Democracy satisfaction & 24 & 4.651 & 0.806 & 3.24 & 6.664 \\
\hline Population density & 41 & 120.125 & 125.817 & 2.667 & 493.242 \\
\hline Public expenditure & 41 & 40.227 & 9.497 & 17.35 & 54.386 \\
\hline Hospital beds per thousand & 41 & 4.445 & 2.647 & 1.13 & 13.05 \\
\hline Trade openness & 41 & 82.764 & 47.941 & 23.194 & 285.96 \\
\hline GDP per capita growth & 41 & 2.076 & 1.308 & 0.561 & 5.481 \\
\hline
\end{tabular}


medRxiv preprint doi: https://doi.org/10.1101/2021.07.10.21260297; this version posted July 14, 2021. The copyright holder for this preprint (which was not certified by peer review) is the author/funder, who has granted medRxiv a license to display the preprint in perpetuity.

It is made available under a CC-BY-NC-ND 4.0 International license .

Table 11 - List of countries

Country Country

Australia Latvia

Austria Lithuania

Belgium Luxembourg

Brazil Mexico

Canada Netherlands

Chile New Zealand

Colombia Norway

Costa Rica Poland

Czechia Portugal

Denmark Russia

Estonia Slovakia

Finland Slovenia

France South Africa

Germany South Korea

Greece Spain

Hungary Sweden

Iceland Switzerland

Ireland Turkey

Israel United Kingdom

Italy United States

Japan 
medRxiv preprint doi: https://doi.org/10.1101/2021.07.10.21260297; this version posted July 14, 2021. The copyright holder for this preprint (which was not certified by peer review) is the author/funder, who has granted medRxiv a license to display the preprint in perpetuity. It is made available under a CC-BY-NC-ND 4.0 International license .

\section{Sources, and definitions of the data}

Total cases per million (Covid cases): Number of total cases per million population (from January 1, 2020 to May 26, 2021). Source: Hannah Ritchie and Roser (2020)

Total deaths per million (Covid deaths): Number of total deaths per million population (from January 1, 2020 to May 26, 2021). Source: Hannah Ritchie and Roser (2020)

New cases per million: Number of new cases per million population (from January 1, 2020 to May 26, 2021). Source: Hannah Ritchie and Roser (2020)

New deaths per million: Number of new deaths per million population (from January 1, 2020 to May 26, 2021). Source: Hannah Ritchie and Roser (2020)

ICU patients per million: Total number of Intensive Care Patients per million population (from January 1, 2020 to May 26, 2021). Source: Hannah Ritchie and Roser (2020)

Hosp. patients per million: Total number of hospitalized patients per million population (from January 1, 2020 to May 26, 2021). Source: Hannah Ritchie and Roser (2020)

Covid excess mortality: Excess mortality during Covid-19 (from January 1, 2020 to May 26, 2021). Source: Hannah Ritchie and Roser (2020)

Trust in government: Citizens' confidence in their government. It is measured before the Covid-19 crisis. Source: OECD (2021)

Trust in politicians: Citizens' confidence politicians. It is measured before the Covid19 crisis. Source: European Social Survey (ESS)

Satisfaction with the government: Captures the level of satisfaction with the national government. It is measured before the Covid-19 crisis. Source: ESS

Democracy satisfaction: Measures satisfaction with how democracy works in the country. It is measured before the Covid-19 crisis. Source: ESS

Population density: Population density is midyear population divided by land area in square kilometers. It is measured before the Covid-19 crisis. Source: World Development Indicators (WDI)

Public expenditure: General government total expenditure (\%GDP). It is measured before the Covid-19 crisis. Source: IMF World Economic Outlook (IMF-WEO)

Hospital beds per thousand: Hospital beds per thousand inhabitants (from January 1, 2020 to May 26, 2021). Source: Hannah Ritchie and Roser (2020) 
medRxiv preprint doi: https://doi.org/10.1101/2021.07.10.21260297; this version posted July 14, 2021. The copyright holder for this preprint (which was not certified by peer review) is the author/funder, who has granted medRxiv a license to display the preprint in perpetuity. It is made available under a CC-BY-NC-ND 4.0 International license.

Trade openness: Trade (\%GDP). It is measured before the Covid-19 crisis. Source: WDI

Real GDP per capita growth: Annual percentage growth rate of GDP per capita. It is measured before the Covid-19 crisis. Source: WDI

Above 65 years: Share of people aged 65 years or older (from January 1, 2020 to May 26, 2021). Source: Hannah Ritchie and Roser (2020)

Test policy: Total tests per thousand inhabitants (from January 1, 2020 to May 26, 2021). Source: Hannah Ritchie and Roser (2020)

Positive rate: Covid-19 positive rate (from January 1, 2020 to May 26, 2021). Source: Hannah Ritchie and Roser (2020)

Positive rate: Covid-19 positive rate (from January 1, 2020 to May 26, 2021). Source: Hannah Ritchie and Roser (2020)

Cardio. death: Cardiovascular mortality rate (from January 1, 2020 to May 26, 2021). Source: Hannah Ritchie and Roser (2020)

Diabetes: Diabetes prevalence (from January 1, 2020 to May 26, 2021). Source: Hannah Ritchie and Roser (2020)

Smoke: Share of smokers (from January 1, 2020 to May 26, 2021). Source: Hannah Ritchie and Roser (2020)

Stringency index: This is a composite measure based on nine response indicators including school closures, workplace closures, and travel bans, rescaled to a value from 0 to 100 (100 = strictest) (from January 1, 2020 to May 26, 2021). Source: Hannah Ritchie and Roser (2020)

Reproduction rate: Virus reproduction rate (from January 1, 2020 to May 26, 2021). Source: Hannah Ritchie and Roser (2020)

Vaccinations: Total number of vaccinations per hundred inhabitants (from January 1, 2020 to May 26, 2021). Source: Hannah Ritchie and Roser (2020)

Democracy: Democracy Index. It is measured before the Covid-19 crisis. Source: Teorell et al. (2020)

Gov. Frac: Government fractionalization index. It is measured before the Covid-19 crisis. Source: Database of Political Institutions (DPI)

Yrs Left in Cur. Term: Years Left in Current Term. It is measured before the Covid-19 crisis. Source: DPI 
medRxiv preprint doi: https://doi.org/10.1101/2021.07.10.21260297; this version posted July 14, 2021. The copyright holder for this preprint (which was not certified by peer review) is the author/funder, who has granted medRxiv a license to display the preprint in perpetuity. It is made available under a CC-BY-NC-ND 4.0 International license .

Government polarization: Chief Executive Party Orientation. It is measured before the Covid-19 crisis. Source: DPI

Central bank ind.: Score measuring the degree of Central Bank independence. It is measured before the Covid-19 crisis. Source: Garriga (2016)

Inflation: Consumer prices (annual \%). It is measured before the Covid-19 crisis. Source: WDI

Unemployment: Unemployment rate. It is measured before the Covid-19 crisis. Source: IMF-WEO

Urbanization: Urban population (\% of total population). It is measured before the Covid-19 crisis. Source: WDI

Level dev.: Level of development. It is measured before the Covid-19 crisis. Source: IMF country classifications

Ratings: Foreign currency long-term sovereign debt ratings. It is measured before the Covid-19 crisis. Source: Kose et al. (2017)

Inequality: Gini index. It is measured before the Covid-19 crisis. Source: World Inequality Database (WID)

Financial openness: Capital Account Openness index. It is measured before the Covid-19 crisis. Source: Chinn and Ito (2006)

Human capital: Human capital index. It is measured before the Covid-19 crisis. Source: Penn World Table PWT 10.0

Tightness : Cultural tightness-looseness. It is measured before the Covid-19 crisis. Source: Gelfand et al. (2011) and Eriksson et al. (2021)

Religion : Share of religiously unaffiliated people. It is measured before the Covid-19 crisis. Source: Pew Research Center (2017)

National pride : Legitimacy of the political authorities. It is measured before the Covid-19 crisis. Source: Institutional Profiles Database (IPD)

Percent migrants : International migrant stock. It is measured before the Covid-19 crisis. Source: WDI

Death : Death rate, crude (per 1,000 people). It is measured before the Covid-19 crisis. Source: WDI

Covid Performance Index : Covid Performance Index (March 13, 2021). Source: Lowy Institute 